\title{
Pemberian Dedak Padi yang Difermentasi dengan Bacillus amyloliquefaciens sebagai Pengganti Ransum Komersil Ayam Ras Petelur
}

\author{
The Effect Substitution of Commercial Ration \\ with Rice Bran Fermented with Bacillus amyloliquefaciens \\ on Performans of Layer
}

Wizna dan H. Muis

Fakultas Peternakan Universitas Andalas

Kampus Unand Limaub Manis Padang 25163

Email:wiznazhari57@yahoo.co.id

(Diterima:18 Desember 2011; Disetujui 16 Maret 2012)

\begin{abstract}
This experiment was carried out to study the effect of substitution of TSI ration with rice bran fermented with Bacillus amyloliquefaciens on feed comsumtion, henday production, egg mass and feed convertion of layer. This experiment was designed using a Completely Randomized Design (CRD) with six treatments. Each treatment three replicates at twelve layer each. The treatment were diets which contained substitution of $20 \%(A), 30 \%(B), 40 \%(C), 50 \%(D), 60 \%(E)$ and $70 \%$ TSI with rice bran fermented with Bacillus amyloliquefaciens $(F)$, resvectively. Feed and water was offered ad libitum. Result of this experiment showed that feed comsumtion, henday production, egg mass and feed convertion were highly affected $(P<0.01)$ by treatment but not affected to henday production. It was concluded that substitution of $40 \%$ TSI ration with rice bran fermented with Bacillus amyloliquefaciens was decreased feed comsumtion and feed convertion of layer.
\end{abstract}

Key words : TSI ration, rice bran, fermented, B. amyloliquefaciens, layer

\section{PENDAHULUAN}

Indonesia sebagai salah satu negara produsen beras yang besar di kawasan asia tenggara tentunya akan menghasilkan dedak padi yang cukup melimpah. Dedak padi merupakan hasil sampingan/limbah dari proses penggilingan padi. Menurut hasil penelitian bahwa kurang lebih $8-8.5 \%$ dari berat padi adalah dedak padi. Dengan angka tersebut maka kita dapat memprediksi potensi suatu daerah untuk menghasilkan dedak padi. Misalnya suatu daerah untuk suatu periode panen menghasilkan 1000 ton padi maka dapat diperkirakan daerah tersebut mampu menghasilkan 80 - 85 ton dedak padi. Didalam dedak padi terdapat beberapa bahan seperti eleurone dan lapisan pericarp serta pecahan beras-beras kecil. Nutrien yang terdapat di dedak padi yang berkualitas baik antara lain komposisi kimia bededak padi cukup tinggi: protein 11,3-14,4\%, lemak 15,0$19,7 \%$, serat kasar 7,0-11,4\%, karbohidrat
34,1-52,3\% dan abu 6,6-9,9\% (Lubis et al., 2002). Dengan kandungan serat kasar yang lebih tinggi daripada jagung atau sumber energi yang lain maka menyebabkan dedak padi diberikan dalam jumlah yang terbatas tergantung pada jenis ternaknya.

Zat makanan yang tersisa pada dedak padi yang cukup tinggi memungkinkan limbah ini masih dapat dimanfaatkan. Dipertanyakan apakah zat makanan pada dedak padi juga dapat ditingkatkan pemanfaattannya oleh Bacillus amyloliquefaciens untuk mengimbangi kekurangan ransum komersil, dan jika dapat, seberapa besar kemampuan bakteri ini mengubah zat makanan yang tidak bisa dicerna oleh unggas menjadi lebih tersedia.

Kandungan zat gizi dedak padi yang rendah dapat diperkaya dengan memanfaatkan $B$. amyloliquefaciens sebagai inokulum fermentasi serta suplementasi bahan nutrien seperti urea sebagai sumber nitrogen, mineral 
S dan Zn mineral yang dapat menyokong dan merangsang pertumbuhan mikroorganisme.

Pada penelitian sebelumnya diketahui populasi Bacillus amyloliquefaciens pada dedak padi fermentasi yang disuplementasi dengan urea, $\mathrm{Zn}$ dan sulfur adalah tidak berhingga (tidak bisa dihitung). Interaksi antara suplementasi $\mathrm{Zn}$ dan sulfur $(\mathrm{P}<0.01)$ terhadap bahan kering dan fosfor, interaksi antara urea dan $\mathrm{Zn}$ terhadap protein kasar, tidak terdapat interaksi perlakuan terhadap kalsium. Serat kasar dedak fermentasi yang ditambah feed supplement $\mathrm{Zn}$, urea, dan sulfur berbeda tidak nyata $(\mathrm{P}>0.05)$ pada masingmasing kombinasi perlakuan. Protein kasar yang terbaik diperoleh pada kombinasi perlakuan $\mathrm{Zn} 0.0025 \%$ dan urea $2 \%$ yaitu $22.62 \%$ Kalsium tertinggi pada perlakuan $\mathrm{Zn}$ $0.0025 \%$ dan urea $2 \%$ yaitu $0.30 \%$, fosfor yang paling tinggi $\mathrm{Zn} 0.0025 \%$ dan sulfur $0.4 \%$ yaitu $1.32 \%$. Dari hasil penelitian dapat disimpulkan bahwa kombinasi feed suplemen terbaik untuk mendapat untuk fermentasi dedak pada uji ME, Retensi $\mathrm{N}$ dan kecernaan SK adalah $\mathrm{Zn} 0.0025 \%$, urea $2 \%$ dan sulfur $0.2 \%$ dengan nilai $\mathrm{ME}$, Retensi $\mathrm{N}$ dan kecernaan SK dedak setelah fermentasi nyata lebih baik dibanding sebelum fermentasi.

Jika dedak padi setelah difermentasi nyata lebih baik dibanding sebelum fermentasi baik terhadap kandungan nutrien atau kecernaannya berarti kita bisa menjadikan produk tersebut sebagai bahan utama dalam penyusunan ransum unggas. Kekurangan nutrien dan energi dari ransum dedak padi diharapkan dapat ditutupi oleh aktivitas probitik B. amyloliquefaciens yang terkandung didalam produk tersebut. Bacillus amyloliquefaciens FZB42 memproduksi antifungal lipopeptida, surfactin, fengycin, bacillomycin $\mathrm{D}$ dan antibakterial polyketide bacillaene serta enzim alfa-amilase, beta glucanase, alfa acetolactate, decarboxylase, metalloprotease, hemicellulase, uriase, fitase, maltogenic amylase, protease dan xylanase dan serin protease (Koumoutsi et al., 2004, Luizmeira.com, 2005).

Pada Ternak ayam yang diberi direct feed microbials bakteri dalam sekum menunjukkan peningkatan aktivitas dan produksi asam lemak terbang (Szylit et al., 1988). Asam lemak terbang pada ternak unggas berguna sekali karena selain sebagai sumber energi juga memiliki efek bakteriostatik dan bakterisidal yang dapat menurunkan atau mengeliminir kolonisasi Salmonella thypimurium dalam usus dan sekum (Corrier et al. 1991). Efek adanya asam lemak terbang terhadap sifat bakteriostatik dan bakterisidal saluran pencernaan, disebabkan turunnya $\mathrm{pH}$ dalam usus dan sekum dengan adanya pelepasan proton menyebar kedalam sel bakteri, sehingga dapat memperbaiki tingkat kesehatan unggas dengan menghambat, atau membunuh bakteri patogen (Hinton, 1990).

\section{METODE}

\section{Materi Penelitian}

Penelitian ini menggunakan ayam petelur strain Isa Brown umur 32 minggu sebanyak 156 ekor, dedak padi, inokulum Bacillus amyloliquefaciens, feed suplement berupa urea, sulfur dan $\mathrm{Zn}$, media nutrient agar (NA), aquades. Ransum percobaan ransum komersil Tri Sula Indah (TSI) Produksi Peternakan ayam ras petelur Gunung Nago Padang, yang dikombinasikan dengan dedak padi fermentasi.

\section{Metoda Penelitian}

\section{a. Pembuatan Inokulum Bacillus amyloliquefaciens}

Sebanyak $10 \mathrm{ml}$ aquades dimasukkan kedalam cawan petri yang telah ditumbuhi biakan murni Bacillus amyloliquefaciens, kemudian cawan petri digoyang perlahan dan digerus dengan oase sampai mikroba lepas dari media, lalu dimasukkan kedalam tabung erlemeyer $250 \mathrm{ml}$ yang telah berisi aquades sebanyak $50 \mathrm{ml}\left(10^{12} \mathrm{CFU} / \mathrm{ml}\right)$.

\section{b. Pembuatan Dedak Inokulasi}

Dedak ditambah dengan feed suplement berupa $2 \%$ urea, $0,2 \% \mathrm{~S}$ dan $0,0025 \% \mathrm{Zn}$, kemudian di sterilisasi di dalam autoclave pada suhu $121^{\circ} \mathrm{C}$ tekanan $15 \mathrm{lbs}$ selama 15 menit, kemudian didinginkan pada 
suhu kamar $\left(27^{\circ} \mathrm{C}\right)$. Selanjutnya ditambahkan inokulum cair dengan perbandingan 2:1 (dua bagian media dan satu bagian inokulum) selanjutnya di inkubasi selama 24 jam. Setelah proses inkubasi selesai media dikeringkan dengan oven pada suhu $60-65^{\circ} \mathrm{C}$ sampai kering, sehingga didapatkan produk dedak fermentasi.

\section{c. Metode eksperimen}

Penelitian ini dilakukan dengan metode eksperimen menggunakan Rancangan Acak Lengkap (RAL) dengan 6 perlakuan dan 3 ulangan masing-masing ulangan digunakan 12 ekor ayam ras petelur sebagai unit percobaan. Sebagai perlakuan adalah kombinasi ransum komersil dan dedak padi fermentasi dengan perbandingan : (80:20), (70:30), (60:40), (50:50), (40:60) dan (30:70). Kandungan zat-zat makanan (\%) dan energi metabolisme $(\mathrm{kkal} / \mathrm{kg})$ dedak padi fermentasi dan ransum ayam ras petelur dapat dilihat pada Tabel 1. Komposisi dan kandungan zat-zat makanan (\%) serta energi metabolisme (kkal/ $/ \mathrm{kg})$ ransum perlakuan dapat dilihat pada Tabel 2. Peubah adalah konsumsi ransum, produksi telur harian (\%), massa telur (gram) dan konversi ransum.

Data yang diperoleh diolah secara statistik dengan menggunakan analisis keragaman Rancangan Acak Lengkap (RAL) menurut Steel and Torrie (1995). Perbedaan antar perlakuan diuji dengan uji jarak berganda Duncan (DMRT) pada taraf $5 \%$.

\section{HASIL DAN PEMBAHASAN}

Rataan konsumsi ransum, produksi telur harian, massa telur dan konversi ransum ayam ras petelur dari tiap perlakuan selama penelitian dapat dilihat pada Tabel 3.

Berdasarkan analisis keragaman dan uji lanjut terhadap konsumsi ransum, massa telur, konversi ransum dan produksi harian ayam ras petelur memperlihatkan bahwa pemakaian dedak padi fermentasi sampai level $40 \%$ dalam ransum memberikan pengaruh yang berbeda tidak nyata $(\mathrm{P}>0,05)$.

Berbeda tidak nyatanya perlakuan pemakaian dedak padi fermentasi sampai level $40 \% \quad(\mathrm{P}>0.05)$ terhadap konsumsi ransum disebabkan oleh dedak padi fermentasi yang diberikan telah meningkat palatabilitasnya karena produk fermentasi biasanya menghasilkan flavour yang khas, sehingga produk tersebut disukai oleh ayam. Sesuai dengan pendapat Murugesen et al. (2005), produk fermentasi mempunyai flavour yang lebih disukai dan mengahasilkan beberapa vitamin seperti $B_{1}, B_{2}$ dan $B_{12}$ sehingga lebih disukai bila dibandingkan dengan bahan yang tidak difermentasi.

Berbeda tidak nyatanya perlakuan pemakaian dedak padi fermentasi sampai level $40 \%(\mathrm{P}>0.05)$ terhadap produksi telur ayam ras petelur disebabkan karena kualitas protein dalam ransum terutama kandungan asam-asam amino esensial ransum A, B, C lebih seimbang dari ransum yang lebih tinggi persentase dedak fermentasinya. Hal ini sesuai dengan pendapat Scott et al (1982) menyatakan bahwa kualitas dari protein sangat berperan dalam menentukan produksi telur, dan ditambahkan oleh Rasyaf (1994) menyatakan bahwa semua zat-zat makanan asam amino esensial (methionin, lisin, trypthopan) diperlukan untuk produksi. Hal ini juga disebabkan oleh bakteri Bacillus amyloliquefacien selain berfungsi sebagai probiotik bakteri ini juga bersifat selulolitik yang menghasilkan enzim selulase dan hemiselulase (Wizna et al., 2007) dan enzim membantu mencerna serat kasar di usus halus sehingga menghasilkan asam-asam organik yang sebagian besar asam asetat diserap dan digunakan dalam tubuh sama halnya dengan glukosa. Wizna et al. (2009), bahwa dalam dedak padi sebagai pengemban probiotik terdapat $40 \times 10^{22}$ CFU/gram Bacillus amyloliquefaciens dalam bentuk spora dan Wizna (2006) selanjutnya diusus halus ayam broiler yang diberi $0,6 \times 10^{7} \mathrm{CFU} / \mathrm{ml}$ Bacillus amyloliquefaciens masih ditemukan 19,58 x $10^{10} \mathrm{CFU} /$ gram berat segar usus halus. Faktor lain yang mempengaruhi kecernaan dan penyerapan serat kasar adalah bentuk dan jenis serat kasar itu sendiri, seperti dijelaskan oleh Anggorodi (1985) bahwa dalam proses pencernaan serat kasar dengan pertolongan bakteri, maka hasil utama yang dapat digunakan adalah asam-asam organik sebagian 
besar asam asetat, asam-asam organik kemudian diserap dan digunakan dalam tubuh sama halnya dengan glukosa.

Rendahnya konversi ransum pada perlakuan $\mathrm{A}, \mathrm{B}$ dan $\mathrm{C}$ dari pada perlakuan $\mathrm{D}$, $\mathrm{E}$ dan $\mathrm{F}$ disebabkan oleh konsumsi ransum dan massa telur yang juga berbeda tidak nyata $(\mathrm{P}>0.05)$ pada perlakuan tersebut. Berarti pada perlakuan $\mathrm{A}, \mathrm{B}$ dan $\mathrm{C}$ terdapat keseimbangan antara ransum yang dikonsumsi dengan massa telur. Prihatman (2000) yang menyatakan bahwa konversi ransum merupakan perbandingan antara ransum dan menghasilkan ransum yang dimakan. Bila ayam itu makan terlalu banyak dan bertelur sedikit maka hal ini merupakan cerminan buruk bagi ayam itu.

Konversi ransum ayam ras petelur selama penelitian ini berkisar antara 2,11 2,57 angka ini tidak jauh berbeda dengan konversi ransum ayam petelur coklat strain Isa Brown umur 20 minggu adalah 2.14-2.35 (Wibowo, 2008) dan juga dengan Guntoro (2000) yang menyatakan bahwa konversi ransum ayam ras petelur dengan pemanfaatan enzim yaitu 2.62

Hal lain yang diduga penyebab tidak terjadinya penurunan peforma ayam ras petelur disebabkan oleh adanya peranan dari spora B.amyloliquefaciens yang terbawa bersama produk fermentasi. Spora Bacillus amyloliquefaciens yang berkembang di dalam saluran pencernaan mengeluarkan beberapa enzim sehingga meningkatkan kecernaan ransum. Sesuai dengan laporan perusahaan makanan yang memproduksi secara komersil beberapa enzim yang hasilkan oleh mikroba, diantaranya enzim yang dihasilkan oleh B.amyloliquefaciens adalah alfa-amilase, alfa acetolactate decarboxylase, beta glucanase, hemicellulase, maltogenic amylase, protease dan xylanase (luizmeira.com).

\section{KESIMPULAN}

Dari hasil penelitian dapat disimpulkan bahwa pemakaian dedak padi fermentasi dengan Bacillus amyloliquefaciens sampai level $40 \%$ pengganti ransum komersil tidak mengganggu performa ayam ras petelur.

\section{DAFTAR PUSTAKA}

Anggorodi, R. 1985. Kemajuan Mutakhir dalam Ilmu Makanan Ternak Unggas Fakultas Peternakan. IPB. Bogor.

Corrier, D.E., B. Hargis, A. Hinton, Jr., D. Lindsey, D.Cadel, J. Manniso, and J.R. De Loach. 1991. Effect of an aerobic cecal microflora and dietary lactose on colonization resistance of layer chicks to invasive Salmonella enteritidis. Avian.

Hinton, M. 1990. Antibacterial activity of short-chain organic acids. Vet. Rec. 126 370.

Koumoutsi, A., X. Chen, A. Henne, H. Liesegang, G. Hitzeroth, P. Franke, J. Vater and R. Borriss. 2004. Scanning electron micrograph of a pea root with adhering B. amyloliquefaciens cells. Bacteriology. pp. 1084-1096, vol. 186,No. 4.

Luizmera. 2005. Enzimas. USD Recomendar esta Pagina. Luizmera.com/enzimas. htm. 2 Maret 2005

Lubis, S., R. Rachmat, Sudaryono., S. Nugraha. 2002. Pengawetan dedak dengan metode inkubasi. Balitpa Sukamandi, Kerawang

Murugesen, G.S., M. Sathishkumar, and Swarninathan. 2005. Suplementation of waste ea fungal biomass as a dietary ingredien for broiler chicken. Bioresource Tegnology 96: 1743-1748.

NRC. 1984. Nutrien Requirement of Poultry. Eight Revied Ed. National Academy Press. Washington. DC.

Scott, M. L., M. C. Nesheim and R. J. Young. 1982. Nutrition of the Chicken. $3^{\text {th }}$ Ed. M. L. Scott and Associates. Ithaca, New York.

Steel, R.G.D and J.H Torrie. 1989. Prinsip dan Prosedur Statistika suatu Pendekatan Biometrik. Ed.ke-2. Terjemahan B. Sumantri. Gramedia Pustaka Utama. Jakarta 
Szylit O. and G. Charlet, 1988. Energy and protein retention in holoxenic, axenic, and gnotobiotic chicken monoassociated with Lactobacillus sp. Journal Britis Poultry Csi. 22 : 305-315.

Wizna. 2006. Potensi Bacillus amyloliquefaciens Isolat Serasah Hutan Dalam Peningkatan Kualitas Pakan Campuran Empelur Sagu Dan Isi Rumen Dan Implikasinya Terhadap Produktivitas Ternak Unggas. Disertasi Pascasarjana Universitas Andalas. Padang.

Wizna, H. Abbas, Y. Rizal, A. Dharma dan I.

P. Kompiang. 2007. Selection and identification of cellulase-producing bacteria isolated from the litter of mountain and swampy forest. Microbiology Indonesia Journal, December 2007, P 135-139 Volume 1, Number 3 ISSN 1978-3477

Wizna, Hafil Abbas, Yose Rizal, Abdi Dharma and I. Putu Kompiang. 2009. Improving the quality of Tapioca ByProducts (Onggok)as poultry feed through fermentation by Bacillus amyloliquefaciens. Pakistan Journal of Nutrition $\quad 8(10)$ : $\quad 1636-164$

Tabel. 1. Kandungan Zat-zat Makanan (\%) dan Energi Metabolisme (kkal/kg) Ransum Komersil Broiler dan Ayam Ras Petelur (Berat Kering Udara) ${ }^{\mathrm{a}}$

\begin{tabular}{lccccccc}
\hline \multicolumn{1}{c}{ Bahan Pakan } & PK & \multicolumn{1}{c}{ LK } & SK & Ca & P & Abu & ME \\
\hline Dedak padi fermentasi $^{\mathrm{b}}$ & 20.13 & 9.0 & 7.56 & 0.27 & 0.36 & & 2211 \\
Ransum TSI $_{\text {Dedak padi }}{ }^{\mathrm{b}}$ & 17.00 & 7.5 & 5.5 & 3.25 & 1.25 & $5-8$ & 2650 \\
\hline Ned $^{2}$ & 12.00 & 9.00 & 12.00 & 0.12 & 0.21 & - & 1630 \\
\hline
\end{tabular}

Keterangan : a. PT Charoen Pophan (2010), b. Wizna dkk. (2010).

Tabel 2. Komposisi dan Kandungan Zat-zat Makanan (\%) serta Energi Metabolisme (kkal/kg) Ransum Perlakuan Ayam Ras Petelur.

\begin{tabular}{lcccccc}
\hline \multirow{1}{*}{ Bahan Pakan } & \multicolumn{7}{c}{ Ransum Perlakuan (\%) } \\
\cline { 2 - 7 } & $\mathrm{A}$ & $\mathrm{B}$ & $\mathrm{C}$ & $\mathrm{D}$ & $\mathrm{E}$ & $\mathrm{F}$ \\
\hline Dedak padi fermentasi & 20.00 & 30.00 & 40.00 & 50.00 & 60.00 & 70.00 \\
Ransum TSI & 80.00 & 70.00 & 60.00 & 50.00 & 40.00 & 30.00 \\
\hline Total & 100.00 & 100.00 & 100.00 & 100.00 & 100.00 & 100.00 \\
\hline PK (\%) & 17.63 & 17.94 & 18.25 & 18.56 & 18.87 & 19.18 \\
LK (\%) & 7.80 & 7.95 & 8.10 & 8.25 & 8.40 & 8.55 \\
SK (\%) & 5.91 & 6.11 & 6.32 & 6.53 & 6.74 & 6.94 \\
Ca (\%) & 2.65 & 2.37 & 2,06 & 1.76 & 1.46 & 1.16 \\
P (\%) & 1.07 & 0.98 & 0.89 & 0.80 & 0.71 & 0.62 \\
ME (kkal/kg) & 2562 & 2518 & 2474 & 2430 & 2387 & 2343 \\
\hline
\end{tabular}


Tabel 3. Rataan konsumsi ransum, produksi telur harian, massa telur dan konversi ransum ayam ras petelur selama penelitian.

\begin{tabular}{ccccc}
\hline & \multicolumn{4}{c}{ Parameter } \\
\cline { 2 - 5 } Perlakuan & $\begin{array}{c}\text { Konsumsi } \\
\text { Ransum } \\
\text { (gram/ekor/hari) }\end{array}$ & $\begin{array}{c}\text { Massa Telur } \\
\text { (gram/ekor/hari) }\end{array}$ & $\begin{array}{c}\text { Konversi } \\
\text { Ransum }\end{array}$ & $\begin{array}{c}\text { Produksi Harian } \\
(\%)\end{array}$ \\
\hline A (80:20) & $112,75^{\mathrm{a}}$ & $56,77^{\mathrm{a}}$ & $2,22^{\mathrm{a}}$ & $88,34^{\mathrm{a}}$ \\
B (70:30) & $117,75^{\mathrm{a}}$ & $55,71^{\mathrm{a}}$ & $2,11^{\mathrm{a}}$ & $92,00^{\mathrm{a}}$ \\
C (60:40) & $118,40^{\mathrm{a}}$ & $54,09^{\mathrm{a}}$ & $2,19^{\mathrm{a}}$ & $88,22^{\mathrm{a}}$ \\
D (50:50) & $124,46^{\mathrm{b}}$ & $50,38^{\mathrm{b}}$ & $2,47^{\mathrm{b}}$ & $64,44^{\mathrm{b}}$ \\
E (40:60) & $128,40^{\mathrm{b}}$ & $51,16^{\mathrm{b}}$ & $2,51^{\mathrm{b}}$ & $68,22^{\mathrm{b}}$ \\
F (30:70) & $129,46^{\mathrm{b}}$ & $50,37^{\mathrm{b}}$ & $2,57^{\mathrm{b}}$ & $54,31^{\mathrm{c}}$ \\
\hline SE & 1,78 & 4.11 & 0,01 & 16,4 \\
\hline
\end{tabular}

Keterangan: - $\quad$ Superskrip yang berbeda dalam kolom menunjukkan pengaruh berbeda sangat nyata $(\mathrm{P}<0.01)$ - SE : standar error 